\title{
Study of Subclinical Mastitis Control on Dry Cow Therapy (DCT) during the Dry Period
}

\author{
Nurhayati IS ${ }^{1}$, Sudarnika $E^{2}$, Zahid $I^{2}$ \\ ${ }^{1}$ Indonesian Center for Animal Research and Development \\ Jl. Raya Pajajaran, Kav. E-59, Bogor 16128, West Java, Indonesia \\ ${ }^{2}$ Faculty of Veterinary Medicine, Bogor Agricultural University, Jl. Agatis, Dramaga, Bogor \\ imasnurhayati_66@yahoo.co.id
}

\begin{abstract}
This aim of study was to indentify the variables supporting the dairy farmers on dry cow therapy (DCT) for contoling subclinical mastitis and impact of the treatment impact on milk production at KPSBU, Lembang, West Java Province. The study was conducted by interviewing the farmers using questionnaires and testing subclinical mastitis using IPB-1 reagen. This study showed that variables supporting the dairy farmers to apply DCT were the attending farmers meeting Odds Ratio $(\mathrm{OR})=4.05$; Confidence Interval $(\mathrm{CI})=95 \%(1.36-12.04)$ and number of productive dairy OR $=5.3$; CI 95\% (1.43-19.58). The DCT programs were able to improve milk production. The milk production increased 620.5 (76.3-1164.7) litre per cow per year.
\end{abstract}

Key Words: Dry Cow Therapy, Milk Production, Subclinical Mastitis

\section{INTRODUCTION}

Mastitis is a major problem in the management of dairy farm because it could potentially reduce milk production in large quantities. Prevention and controling of diseases indispensable as one of the disease control measures in the field.

Subclinical mastitis in Indonesia until the end of 2006 were approximately $75-83 \%$ (Sudarwanto et al. 2006). Based on previous studies conducted in the Island of Java, reported that the prevalence of subclinical mastitis was 37-67\%, while clinical mastitis 5$30 \%$ could cause USD 8.5 M economic losses per year if no control measures were intensified (Sufar 1997). Economic losses can be caused by a decreased in milk production per quarters per day (9-45.5\%), decreased quality of milk 30-40\% (Sudarwanto 1999), decreased quality of dairy products and early culling.

The occurrence of subclinical mastitis is an interaction between cattle, the causative agent and the environment. Microorganisms are most likely to cause subclinical mastitis are bacteria (80\%). Subclinical mastitis-causing bacteria include Staphylococcus aureus, Staphylococcus epidermidis, Streptococcus dysgalactiae, Streptococcus agalactiae and Streptococcus uberis as well as especially coliform bacteria Escherichia coli and Klebsiella (Sharif et al. 2009). According to Hameed \& Sender (2006) subclinical mastitis caused by $S$. dysgalactiae, E. coli and other bacteria that cause mastitis. S. aureus is a bacteria that causes most of subclinical mastitis, these bacteria can move between quarters during the milking process so that transmission occurs (Marogna et al. 2010). The incidence of mastitis caused by bacteria from the environment can occur at any time, with the source of infection in the form of the environment around the cow (Hillerton \& Berry 2005).

The major predisposing factors of subclinical mastitis in animals is udder. Hanging udders or udders with big nipples hole easily infected (Akers et al. 2006). Septiani (2013) in his research concluded that the length of the nipple and the period of lactation dairy cows is a predisposing factor for subclinical mastitis, and the highest correlation occurs with an average length of $7.5 \mathrm{~cm}$ and have nipples that are in the third and fourth lactation period. Cases of mastitis on hanging udder were reported higher than the case of mastitis 
on normal position of the udder (Sori et al. 2005). This happens because of the hanging udder potencially exposure to pathogenic agents is higher so that pathogens are more easily attached and entry into the udder. Infection generally occurs during the dry period especially two weeks after cessation of milking and two weeks ahead of time to give birth. According Sarker et al. (2013), four different factors are significantly associated with the occurrence of subclinical mastitis and required attention in disease control, namely the history of clinical mastitis before, conditions udder hanging, not fed with grass, and the value of body condition (body condition score/BCS). Mammary gland is very sensitive to the possibility of infection before giving birth and early lactation (Hillerton \& Berry 2005; Schrick et al. 2001). The incidence of subclinical mastitis that occurs during the dry period reaches $63 \%$ (Pantoja et al. 2009).

Dry cow therapy is one of alternative way for controlling mastitis, because have several advantages, they are: (1) Dry cow therapy has a success rate of about $80-90 \%$ when compared to administration of antibiotics during lactation with a success rate of about 30-40\% (Waldner 2014); (2) Other than that the doses used in the treatment measures can be higher and safer, because the retention time of the drug in the udder becomes longer; (3) The risk of contamination of antibiotics in milk can be avoided because the milk is not milked; and (4) Is the best way to treat subclinical mastitis and chronic mastitis which is difficult in lactation. In addition, dry cow therapy can be applied easily by the farmers because of the drug are available in special packaging that is easily applied by farmers.

However, subclinical mastitis disease control programs have not been fully followed by the farmers. So this study was conducted to indentify the variables supporting the dairy farmers to apply dry cow therapy, dry cow therapy relationship to the incidence rate of subclinical mastitis cases and the effect of the antibiotic to the increase in milk production.

\section{MATERIAL AND METHODS}

The study was conducted by using a case-control study design with comparison between cases and controls 1:1. The dairy farmers who treat their dry cow during dry period represent as cases and without any treatment as controls. Determination cases and controls were based on the list of farmers who treat their dry cow in KPSBU Lembang. Total respondents were 110 dairy farmers. They were 55 dairy farmers who apply dry cow therapy (DCT) and others were 55 dairy farmers who did not apply DCT (non-DCT). Subclinical mastitis tests were done on two lactating cows for each farmer per group. Subclinical mastitis tests were performed using reagents IPB-1. The dairy cow were categorised positive for subclinical mastitis infection if one or more quarter cow showed positive results. Respondents were selected randomly in five places with cooperative services where were determined from 23 locations.

Table 1. Number of respondents and dairy samples for testing subclinical mastitis

\begin{tabular}{lcccc}
\hline \hline $\begin{array}{l}\text { Places cooperative } \\
\text { services }\end{array}$ & DCT & Non-DCT & Respondents (farmers) & Dairy samples (head) \\
\hline Cibodas & 11 & 11 & 22 & 44 \\
Manoko & 11 & 11 & 22 & 42 \\
Pencut & 11 & 11 & 22 & 44 \\
Cibogo & 11 & 11 & 22 & 44 \\
Barunagri & 11 & 11 & 22 & 44 \\
\hline Total respondents & 55 & 55 & 110 & 218 \\
\hline
\end{tabular}




\section{RESULTS AND DISCUSSION}

\section{Control measures through dry cow mastitis therapy in KPSBU Lembang}

Mastitis control was applied at KPSBU Lembang DCT. The period 2009-2012, farmers appling DCT were 2159, 2812, 2455, 2025, from 4359 active member. The number of farmers who apply the DCT lower than no therapy. It probably related to the level of understanding of the benefits of DCT. The farmers who treated their dry cow were generally the same farmers for every year. Thus, to increase the participation of farmers in the control measures was required appropriate counseling, so that farmers awareness of dry cow therapy might be also increasing.

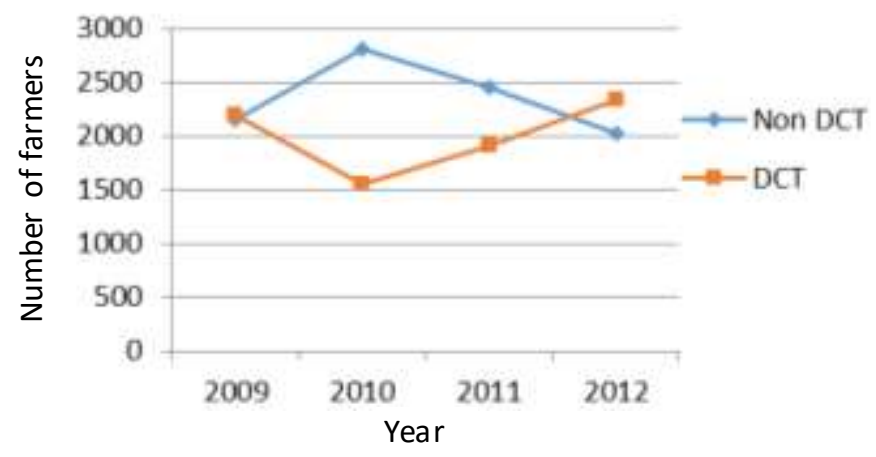

Figure 1. The numbers of farmers who do dry cow therapy in KPSBU Lembang

Dry cow therapy policy has been long time implemented in the KPSBU, Lembang, Java province, however the management of KPSBU was not evaluated by doing an assessment of this policy. The results of this study was expected to be useful for the management of KPSBU to improve they services.

\section{Variables which supported the dairy farmers to apply dry cow therapy}

Based on the results of the chi square test on age, level of education, the main work, the experience of raising, business ownership, attending farmers for a meeting and the number of productive dairy were only four variables that can be continued for further analysis using multiple logistic regression model. They were level of education, the main work, attending farmers for a meeting and the number of productive dairy. The result of multiple regression model revealed that two variables supporting the farmers to apply the dairy cow therapy, attending farmers for a meeting and the number of productive dairy.

Table 2. Variables supporting the dairy farmers to apply the DCT

\begin{tabular}{lccc}
\hline \hline Variable & Odds ratio & Calving interval & P value \\
\hline $\begin{array}{l}\text { Attending farmers for a } \\
\text { meeting }\end{array}$ & 4.05 & $1.36-12.04$ & 0.012 \\
Number of productive dairy & 5.29 & $1.43-19.58$ & 0.012 \\
Level of education & 2.032 & $0.174-1.101$ & 0.078 \\
The main work & 0.438 & $0.718-5.749$ & 0.182 \\
\hline
\end{tabular}

Farmers who actively participated in the group meetings (89\%) would have 4.05 (1.36 to 12.04) time possibilities to apply DCT in the dry period compared to passive farmers. It 
indicated that the farmers have a good understanding of the benefits of DCT. According to Gerungan (1996) that knowledge of an object will foster a positive attitude towards the object if the knowledge is accompanied by a readiness to act in accordance with the knowledge of the object. The attitude will determine actions or practices (behavior). Someone who has a positive attitude toward an object, it is likely also to act positively towards the object. Their positive attitude is based on the existence of thought and knowledge of the object (Sujarwo 2004).

The farmers who performed five lactating cows (75\%) would have 5.29 (1.43 to 19.58) time possibilities to apply DCT during dry period when compared to farmers who have less than five lactating cows. It could happen because the first group of farmers have a better purchasing power than others group. In addition, the farmers did not economically depend on the milk production, so that they did not have a good motivation to take care of their business well. In this second group of farmers, the price of milk was lower than the maintenance costs, so that the farmers were reluctant in spending money for purchasing drugs for their livestock. To improve the service quality for members, the DCT during the dry period might be considered as one of alternative way for the cooperative management to be incorporated into the component handling cost, giving the composition to dairy farmers in Indonesia, particular for the farmers with low ownership rate (raising less than five cows; 80\%) with relatively low income. Thus, the cooperative member could utilize the handling cost (Rp. 560.32/litres of milk for every day). The subclinical mastitis control measures through the DCT during dry period would be carried out intensively. This is supported by Rusidi (2002) stating that as a customer, the members take advantage of a variety of potential/services provided by the cooperative in support of its interests.

Instead an inhibiting factor of action dry cow therapy is the low purchasing power of farmers with a low number of lactating cows and farmers are passive in following the activities of group meetings. Farmers who are passive in general have a low understanding of the benefits of dry cow therapy because of the lack of information held. Extension is expected to improve the understanding of farmers about the benefits of subclinical mastitis control, especially farmers who are passive are extension activities that are personal (face to face communication).

\section{Dry cow therapy relationship to the incidence rate of subclinical mastitis cases}

Table 3 shows the results of subclinical mastitis test in each group, the farmers who apply DCT and non DCT during the dry period. Number of subclinical mastitis cases was higher in the non DCT group. The analysis showed that the DCT at dry period showed a significant effect on the incidence of subclinical mastitis in the field $(\mathrm{P}<0.05)$.

Table 3. The test results of subclinical mastitis by IPB-1

\begin{tabular}{lccc}
\hline \hline \multirow{2}{*}{ Treatment } & \multicolumn{3}{c}{ Subclinical mastitis test results } \\
\cline { 2 - 4 } & Negative & Positive & Total \\
\hline Non-DCT & $10(9.26 \%)$ & $98(90.74 \%)$ & 108 \\
DCT & $29(26.36 \%)$ & $81(73.64 \%)$ & 110 \\
\hline Total & $39(17.89 \%)$ & $179(82.11 \%)$ & 218 \\
\hline
\end{tabular}

Based on Table 3, the values of odds ratio is 3.5 (1.6-7.6). The non-DCT group has a possibility 3.5 (1.6-7.6) time for subclinical mastitis disease compared to the DCT group. The result was in line with the previous studies that aplication of antibiotics during dry period able to reduce of new infection, both at the beginning and towards the end of the 
dry period. It is related to physiological changes in the mammary gland. Smith et al cited by Sharif et al. (2009) stated that aplication of antibiotics during dry period can reduce new infections was around $82 \%$. The same statement also was mentioned by Waldner (2014) that the DCT rate was about $80-90 \%$ when compared to administration of antibiotics during lactation with rate about 30-40\%. According to Mackintosh (2015) that aplication of DCT has several benefit by reducing the number of mastitis cases, the number of somatic cells, animal welfare issue, and herd management. In addition, Smith \& Hogan (1993) stated that treatment with appropriate antibiotics in all quarters during dry period could help to control Streptococcus sp. Application of antibiotic during dry period is a very specific control against infection intra mamary to avoid economic losses (Halasa et al. 2010). The number of the cases in the group of animals given antibiotics during the dry was less compared with the group given no antibiotics (Bhutto 2011). Bradley (2011) also reiterated the importance of prevention of new intramammary infection in the dry period.

\section{Dry cow therapy relationship to the production of milk}

Based on the analysis of $\mathrm{T}$ test that application of DCT during the dry periodd provides significant benefit to increase milk production. Milk production in the group of farmers which apply DCT during the dry period was 5750.4 \pm 217.38 litres/cow/year. However, for non DCT group has a milk production by $5129.9 \pm 167.68$ litres/cow/year. Group of farmers applying DCT during the dry period has higher milk production in average 620.5 (76.3-1164.7) litres/cow/year than another. The results of similar studies is also presented by Supar \& Ariyanti (2008) that the control of subclinical mastitis with dry cow therapy during dry period can increase milk production. This happens because the antibiotics during dry period could control the incidence rate of subclinical mastitis through somatic cell count control. Thus the number of somatic cells as a result of giving antibiotics during dry period along with the increase in milk production.

\section{Economic analysis of dry cow therapy}

The potential for increasing milk production through the action of treatment of mastitis at the dry period can provide improved considerable profit to the farmers. If the analysis was done through a partial budgeting, the average increase in milk production of 620.5 litres/head/year. If the average price of milk at the farm level amounting to $\mathrm{Rp}$. 3,407/litre, then the increase in production could have a profit of Rp. 2,049,044/cow/year.

If we compared to the average production of milk per cow per year in KPSBU Lembang amounted to 5,440.2 litres, then the milk production in the group of farmers who apply dry cow therapy at dry period increased by 620.5 litres, or by $11.4 \%$. But compared with the previous research conducted by Supar \& Ariyanti (2008) in Sukabumi, increase milk production during the 90-day production period a total of 295 litres, thus the increase in milk production in the region KPSBU Lembang is still relatively low. Dry cow therapy during at dry period should be accompanied by improved management of milking. It is also in line with the statement Supar \& Ariyanti (2008) that the control measures of subclinical mastitis in dry cow therapy is accompanied with a good milking management can reduce the incidence of subclinical mastitis and increase milk production.

Based on the results of statistical and economic analyses, that measuring mastitis control through the DCT during the dry period was effective. It could suppress the incidence of subclinical mastitis. Moreover, the DCT could also economically provide greater benefit to the farmers. Thus, the DCT program during the dry period was one of the 
appropriate policy on controlling subclinical mastitis in the field. However, application of this policy should be supported with adequate extension action, so that farmers have the knowledge and understanding of the benefits of this policy.

Table 5. Economic analysis of dry cow therapy through a partial budgeting

\begin{tabular}{ll}
\hline \hline Component analysis & \multicolumn{1}{c}{ Result } \\
\hline The difference milk production after DCT & 620.5 litres/head/year \\
Additional charges for DCT & Rp. 65,000/head/year \\
The difference in profits & Additional income-additional charges \\
& $(620.5 \times$ Rp. 3,407) - Rp. 65,000 \\
& Rp. 2,114,044 - Rp. 65,000 \\
Rp. 2,049,044/head/year
\end{tabular}

Rp. 3,407 an average price of milk at farm level in the area KPSBU Lembang

If the prevalence of the disease is $75 \%$ of the total cow population (15,000 heads), it means that 11,250 head had infections. When the action had been performed on all cow, then KPSBU Lembang gained profits as follows:

620.5 litres /head/year $\times 11,250 \times$ Rp. 3,407 = Rp. 23,782,989,375 follows:

Additional costs for the DCT that must be issued to the infected population is as

$$
\text { Rp. } 65,000 \times 11,250=\text { Rp. } 731,250,000
$$

When calculated with the additional expenditure to be incurred for the cost of treatment to all infected cow, the disease control economically remains profitable because they provide a potential profit of Rp. 23,051,739,375 per year.

\section{CONCLUSION}

This study showed that variables supporting the dairy farmers to apply DCT were the attending farmers for a meeting and number of productive dairy. The DCT were able to improve milk production per year. It could suppress the incidence of subclinical mastitis if it apply in the field.

\section{REFERENCES}

Akers RM, Capuco AV, Keys JE. 2006. Mammary histology and alveolar cell diffrentiation during late gestation and early lactation inn mammary tissue of beef and dairy heifers. Livest Sci. 105:44-49.

Bradley AJ, Breen JE, Payne B, Green MJ. 2011. A comparison of broad-spectrum and narrowspectrum dry cow therapy used alone and in combination with a teat sealant. J Dairy Sci. 94:692-704.

Bhutto AL, Murray RD, Woldehiwet Z. 2011. The effect of dry cow therapy and internal teatsealant on intra-mammary infections during subsequent lactation. Res Vet Sci. 90:316-320.

Gerungan WA. 1996. Psikologi sosial, suatu ringkasan. Bandung (Indonesia): Eresco.

Hameed KGA, Sender G. 2006. Public health hazard due to mastitis inn dairy cows. Anim Sci Papers Reports. 25:73-85. 
Halasa T, Nielen M, Werven TV, Hogeveen. 2010. A simulation model to calculate cost and benefits of dry period interventions in dairy cattle. J Livest Sci. 129:80-87.

Hillerton JE, Berry EA. 2005. Treating mastitis in the cow is a tradition or an archaism. J Appl Microbial. 98:1250-1255.

Mackintosh D. 2015. Antibiotics and dry cow therapy: What's the problem? [Internet]. Available from: http://www.kellogg.org.nz/fileadmin/kellogg/Documents/Course_1/Mackintosh D_Antibiotics_and_Dry_Cow_Therapy_-_What_s_the_problem.pdf.

Marogna G, Sandro R, Stefano L, Sebastian T, Guido L. 2010. Clinical findings in dairy farms affected by recurrent bacterial mastitis. Small Rumin Res. 88:119-125.

Rusidi. 2002. Paradigma dimensional bagi pengembangan teori-teori koperasi. Dalam: Rusidi, Suratman, penyunting. 20 Pokok Pemikiran tentang Pembangunan Koperasi. Sumedang (Indonesia): UPT Penerbitan Ikopin.

Sarker SC, Parvin MS, Rahman AKMA, Islam MDT. 2013. Prevalence and risk factors of subclinical mastitis in lactating dairy cows in North and South regions of Bangladesh. Trop Anim Health Prod. 45:1171-1176

Sharif A, Umer M, Muhammad G. 2009. Mastitis control in dairy production. J Agric Soc Sci. 5:102-105.

Schrick FN, Hockett ME, Saxton AM, Lewis MJ, Dowlen HH, Oliver SP. 2001. Influence of subclinical mastitis during early lactation on reproductive parameters. J Dairy Sci. 84:14071412.

Septiani YN. 2013. Panjang puting dan period laktasi sebagai faktor predisposisi mastitis subklinis pada sapi perah di KPSBU Lembang Kabupaten Bandung [Skripsi]. [Bogor (Indonesia)]: Fakultas Kedokteran Hewan, Institut Pertanian Bogor.

Smith KL, Hogan JS. 1993. Environmental mastitis. Vet Clin N Amer. 9:489-498.

Sori H, Zerihum, Abdicho S. 2005. Dairy cattle mastitis in and around Sebeta, Ethiopia. Int J Appl Res Vet Med. 3:332-338.

Sudarwanto M. 1999. Usaha peningkatan produksi susu melalui program pengendalian mastitis subklinis. Orasil lmiah. 22 Mei 1999.

Sudarwanto M, Latif H, Noordin M. 2006. The relationship of the Somatic cell counting to subclinical mastitis to improve milk quality. In: $1^{\text {st }}$ International AAVS Scientific Conference. Jakarta, $12^{\text {th }}-13^{\text {th }}$ July 2006. Jakarta (Indonesia).

Sujarwo. 2004. Pengetahuan, sikap dan tindakan masyarakat sekitar hutan dalam pelestarian hutan (kasus di Hutan Diklat Tabo-Tabo, Kabupaten Pangkep, Provinsi Sulawesi Selatan) [Tesis]. [Bogor, Indonesia)]: Institut Pertanian Bogor.

Supar, Ariyanti T. 2008. Kajian pengendalian mastitis subklinis pada sapi perah. Dalam: Diwiyanto K, Wina E, Priyanti A, Natali L, Herawati T, Prasetyo B, penyunting. Prospek industri sapi perah menuju perdagangan bebas 2020. Bogor (Indonesia): Puslitbangnak. hlm 360-366.

Supar. 1997. Mastitis subklinis pada sapi perah di Indonesia: Masalah dan pendekatannya. Wartazoa. 6:48-52.

Waldner DN. 2014. Dry cow therapy for mastitis control [Internet]. [Diunduh 2014 Jan 10]. Tersedia dari: http://osufacts.okstate.edu/pdf _file/fact sheets/DNWaldner. 